\title{
Irrigation Of Wounds with Red betel $20 \%$ And $40 \%$ to Bacterial Numbers In Diabetic Foot Infection (DFI) Patients
}

\author{
Mayusef Sukmana*, Dwi Nopriyanto, Alhawaris \\ Faculty of Medicine, Mulawarman University, Samarinda, Indonesia \\ Corresponding author: 200801sukmana@gmail.com
}

\begin{abstract}
Background: The most frequent complications of diabetes mellitus are Diabetic Foot Ulcers (DFU), which has a risk of death 2.5 times compared to those without DFU. More than half of them have problems with infection (Diabetic Foot Infections). Research on wound washing to control diabetic wound infections originating from phytopharmaca using tropical natural resources such as red betel has not developed. They are a tropical plant that has many benefits containing flavonoids, tannins, alkaloids, saponins. Washing the wound with irrigation and swab techniques using red betel $20 \%$ effectively reduces the total number of bacteria with diabetic ulcer isolates in white mice alloxan-induced. It reduces staphylococcus growth aureus at concentrations of 10\%, 20\%, 40\%, 80\%, $100 \%$.
\end{abstract}

Purpose: This study aimed to determine the effectiveness of wound irrigation red betel $20 \%$ and $40 \%$ of the bacterial rate in DFI patients.

Methods: This study used a quasi-experiment with pre-post test control group design two treatment groups where bacterial samples were taken before and after irrigation using $20 \%$ and $40 \%$ red betel extracts while the control group used $0.9 \% \mathrm{NaCl}$. Sampling using consecutive sampling with a large sample of 10 respondents, the total sample swab is 20 samples. The Levine technique swab does perform in the area of the diabetic wound. Wilcoxon test was used as a different test in each group showing a group.

Results: The results showed that the Wilcoxon test was used as a different test in each group showing a group. of $20 \%$ p-value 0,109 , group $40 \%$ p-value 0,109 and a dick group p-value 0,180 .

Conclusion: There was a decrease in the number of bacteria after irrigation betel leaf extract in all groups. The $40 \%$ betel extract irrigation group showed an average reduction in bacterial numbers. The DFI wound had an average difference in all groups but was not significant. The suggestion for research follows: Taking more samples, the use of red betel extract as an alternative for infection control in wounds. Further research can be done by isolating the red betel content need for more sampling.

Keywords: Wound Washing, Red Betel, Piper Crocatum, DFI, Bacterial Numbers. 


\section{Journal Of Nursing Practice}

http://thejnp.org

ISSN: 2614-3488 (print); 2614-3496 (online)

Vol.4 No.1. October 2020. Page.51-60

\section{BACKGROUND}

Complications of diabetes mellitus in the form of Diabetic Foot ulcers 20\% have problems expanding infection (DFI), healing old wounds, gangrene, amputation, and death (Armstrong, Boulton, \& Bus, 2017). Open wound infection makes it easy for germs to enter. Infection does characterize by fluid wounds or exudates that are many, smelly. Wound healing is prolonged (Smith et al., 2016). Bacteria form a layer called biofilms, infection develops, decreases the immune system on the wound surface, and interferes with wound healing (Smith et al., 2016). The uncontrolled disease continues osteomyelitis, bacteremia, and sepsis. (I Made Sukma Wijaya, 2018) Infection control does influence by wound washing. This type of washing of electrolyzed strong water acid wounds has a bactericidal effect. It is useful in reducing bacterial colonization (Pramesti, Andiyanti, \& Effendi, 2017b). Superoxidised (oxum), propyl betaine-polihexanide, povidone-iodine, 2\% hydrogen peroxide, chlorine dioxide are bactericidal, whereas $\mathrm{NaCl} 0.9 \%$ and TAP water do not have them (Pramesti, Andiyanti, \& Effendi, 2017a). Form of antiseptic soap to control infections, effectively reducing bacterial colonization compared to ordinary soap (Yusuf \& Tahir, 2018).

Research on wound washing to control diabetic wound infections originating from tropical nature such as betel has not developed. Betel has many benefits, easily cultivated in a tropical climate. The content in the form of flavonoids destroys bacterial extracellular integrity. Tannins destroy bacterial cell membranes. Alkaloids can inhibit glycan peptides so that bacterial cells do not develop fully (Mustofa, 2017). Betel reduces odor in diabetic wounds (Sutrisno \& Hidayat, 2018). Irrigation and swab wound washing using $20 \%$ betel effectively reduces the total number of diabetic ulcer isolate bacteria in alloxan-induced white rats (Purwaningsih, 2016). The combination of $0.9 \% \mathrm{NaCl}$ irrigation and $40 \%$ red betel infusion in diabetic ulcers proved to be more effective in the process of healing diabetic wounds (Pashar, 2018). Ethanol red betel extract has an inhibitory effect on the growth of staphylococcus aureus at concentrations of 10\%, 20\%, 40\%, 80\%, 100\% (Candrasari, Romas, \& Astuti, 2011). Bacteria in the second most DFI Staphylococcus aureus 30\%. (Gaol, Erly, \& Elmatris Sy, 2017). Research problem formulation: How is the effectiveness of wound irrigation using $20 \%$ and $40 \%$ red betel (red betel) against the bacterial reduction in DFI patients?.

\section{OBJECTIVE}

This study aimed to determine the effectiveness of wound irrigation red betel $20 \%$ and $40 \%$ of the bacterial rate in DFI patients.

\section{METHODS}

The research design was a quasi-experiment using pre-post group control: Group I treated with wound irrigation using $20 \%$ leaf extract. Group II treated with a wound. Irrigation using $40 \%$ betel leaf extract. Group III treated with wound irrigation using $0.9 \%$ $\mathrm{NaCl}$. Wound swab collection was carried out before wound irrigation and after wound irrigation using betel leaf extract in all three groups.

Several stages have carried out as follows: making ethanol extract $20 \%$ and $40 \%$ betel leaf is done by maceration. Fresh betel leaves are washed clean and finely sliced, then dried in the shade, continued drying in the drying cabinet for three days. Material that has been dried, blended with a blender to form a powder. 


\section{Journal Of Nursing Practice}

http://thejnp.org

ISSN: 2614-3488 (print); 2614-3496 (online)

Vol.4 No.1. October 2020. Page.51-60

1. Finely ground powder with blander is weighed, mixed with $96 \%$ ethanol, and filtered. The next step is evaporation using a rotary vacuum evaporator with a temperature of 50

${ }^{\circ} \mathrm{C}$.

2. The making $20 \%$ extract liquid, the extract is taken as much as $20 \mathrm{mg}$ and diluted with $100 \mathrm{ml} \mathrm{NaCl}$ and $25 \mathrm{mg}$ DMSO. The extract does obtain a concentration of $20 \%$. The $40 \%$ extract was weighed as much as $40 \mathrm{mg}$ and diluted with $100 \mathrm{ml} \mathrm{NaCl}$ and $25 \mathrm{mg}$ DMSO. The extract does obtain a concentration of $40 \%$. (Sutopo, Bestari, \& Sintowati, 2017) (Eka Wisnu Kusuma, 2019) (Badan POM RI, 2010).
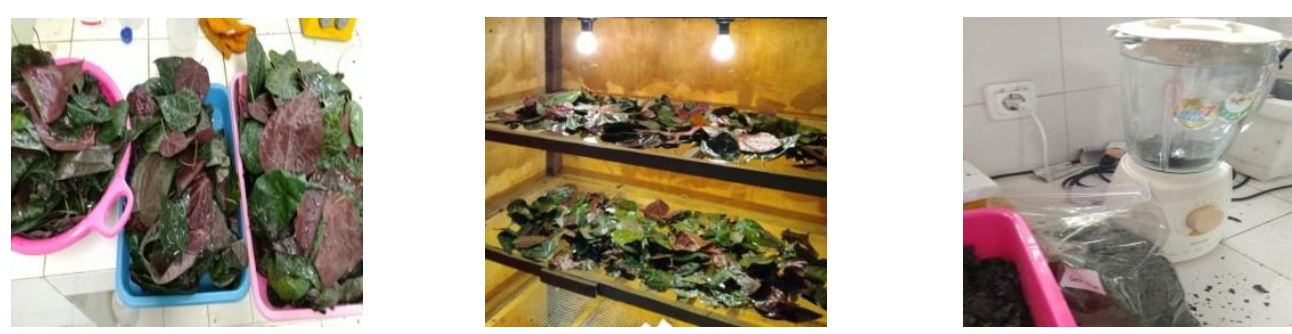

Figure 4. 1 washing, then dried, sliced, blanded
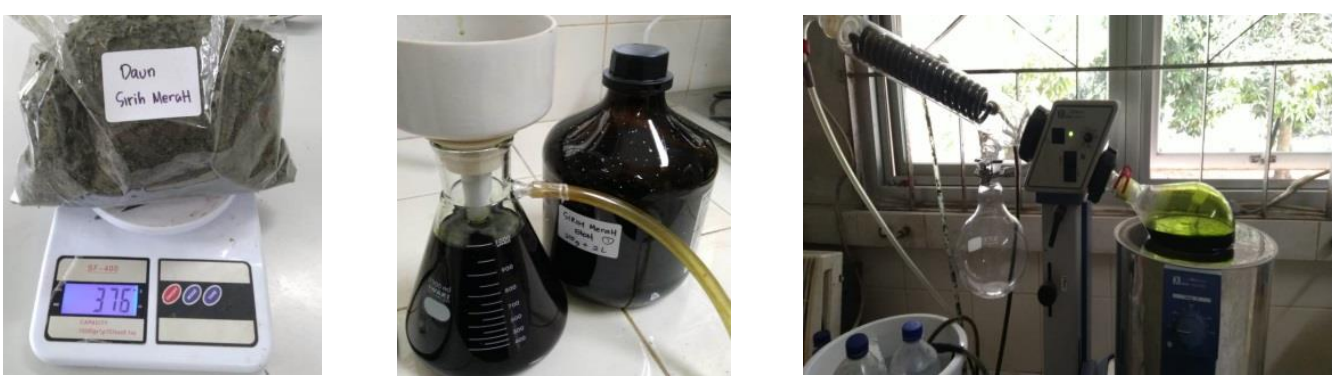

Figure 4.2 weighing, giving ethanol dan rotary evaporator

3. The extract with a concentration of $20 \%$ was put into the syringe as much as $20 \mathrm{ml}$. The needles obtained containing the extract concentration of $20 \%$ do use for the treatment group of $20 \%$ extract irrigation of 5 respondents.

4. The extract with a concentration of $40 \%$ was put into the syringe as much as $20 \mathrm{ml}$. It was used for the treatment group to extract $40 \%$ irrigation as many as five respondents. All extracts that have incorporated into syringes do sterilize with a combination of heat and ultraviolet sterilizers. The temperature used is $120^{\circ} \mathrm{C}$ for 30 minutes and together with ultraviolet exposure for 30 minutes.
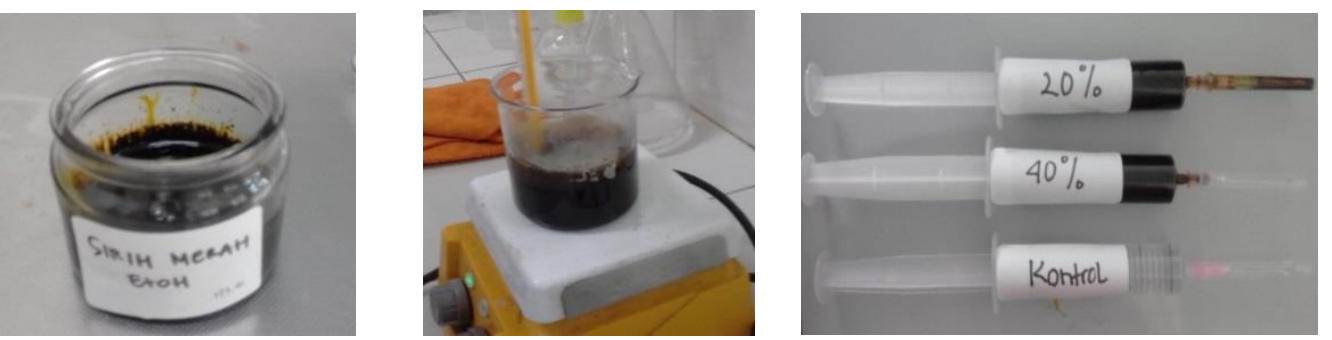

Figure 4.3 Delusion extract process 


\section{Journal Of Nursing Practice}

http://thejnp.org

ISSN: 2614-3488 (print); 2614-3496 (online)

Vol.4 No.1. October 2020. Page.51-60

5. The wound was irrigated with the diluted extract at a $20 \mathrm{ml}$ dose using a $20 \mathrm{ml}$ syringe the size of an 18 gauge needle (attached to the sampling SOP). The frequency of wound irrigation treatment for respondents does only once.

The swab is taking specimens in the area to be examined. Several types of swabs, such as simple techniques, z-stroke techniques, and Levine swab techniques, were often used because they have a high sensitivity reaching 52.9\% (Beta Subakti Nata'atmadja, 2013). Levine's technique is more reflective than others. The method carried out using a swab rotation with a slight pressure on the wound area of $1 \mathrm{~cm} 2$ of granulation tissue to remove the exudate for 5 seconds. (Baranoski \& Ayello, 2015)

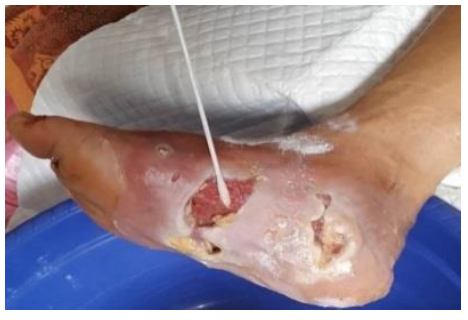

Figure 4. 4 Swab of wound

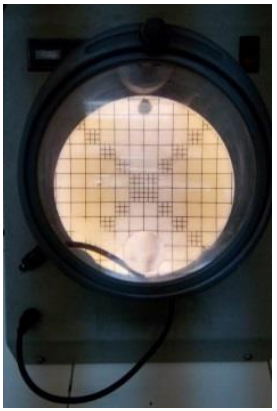

Figure 4.5 Plate count bacterial

The measurement of bacterial was used by the Total Plate Numbers (Eka Wisnu Kusuma, 2019). The examination of bacterial numbers by the total plate count method (Plate Count Total / PCT) carried at the UPTD health laboratory in East Kalimantan Province. The calculation of bacterial cells in the cup used in units of CFU / ml. CFU stands for Colony Forming Unit, which means colony forming units or units.

\section{RESULTS}

Characteristics of respondents can be seen in the table below as follows:

Table 5. 1 Characteristic of respondents based on age, sex, length of wound care, grade PEDIS

\begin{tabular}{lcc}
\hline \multicolumn{1}{c}{ Characteristics } & Amount & $\mathrm{f}(\%)$ \\
\hline Age & 1 & \\
a. 20-30 & 1 & 10 \\
b. 31-40 & 1 & 10 \\
c. 41-50 & 2 & 10 \\
d. 51-60 & 5 & 20 \\
e. 61-70 & 10 & 50 \\
$\quad$ Total & 1 & 100 \\
Sex & 9 & \\
a. Laki-laki & 10 & 10 \\
b. Perempuan & & 90 \\
$\quad$ Total & 6 & 100 \\
Duration of wound care & 3 & 60 \\
a. 2 month & 1 & 30 \\
b. 3 month & & 10 \\
c. 4 month &
\end{tabular}




\section{Journal Of Nursing Practice}

http://thejnp.org

ISSN: 2614-3488 (print); 2614-3496 (online)

Vol.4 No.1. October 2020. Page.51-60

\begin{tabular}{lcc}
\hline Total & 10 & 100 \\
Grade PEDIS & & \\
a. Grade 2 & 7 & 70 \\
b. Grade 3 & 3 & 30 \\
$\quad$ Total & 10 & 100 \\
\hline
\end{tabular}

Table 5.1 shows the most dominant age characteristic is 61-70 years, with many 5 respondents $(50 \%)$. Female sex numbered 9 respondents $(90 \%)$. The longest wound treatment was 2 months, with 6 respondents (60\%) and PEDIS 2 grade of 7 respondents $(70 \%)$.

Tabel 5.2 Calculate bacterial numbers before irrigation, after irrigation and decrease rates in all groups

\begin{tabular}{ccccc}
\hline Respondents & Group & $\begin{array}{c}\text { The bacterial } \\
\text { count of before } \\
\text { irrigate (CFU) }\end{array}$ & $\begin{array}{c}\text { Bacterial } \\
\text { count after an } \\
\text { irrigation } \\
\text { (CFU) }\end{array}$ & $\begin{array}{c}\text { difference } \\
\text { (CFU) }\end{array}$ \\
\hline A1 & $20 \%$ & 372 & 60 & 312 \\
A2 & $20 \%$ & 1 & 1 & 0 \\
A3 & $20 \%$ & 45266 & 41533 & 3733 \\
A4 & $20 \%$ & 147000 & 11125 & 135875 \\
A5 & $20 \%$ & 1 & 1 & 0 \\
B1 & $40 \%$ & 62500 & 57300 & 5200 \\
B2 & $40 \%$ & 19133 & 11 & 19122 \\
B3 & $40 \%$ & 68 & 1 & 67 \\
C1 & $\mathrm{NaCl} \mathrm{0,9 \%}$ & 6300 & 2300 & 4000 \\
C2 & $\mathrm{NaCl} \mathrm{0,9 \%}$ & 79622 & 10000 & 69622 \\
\hline
\end{tabular}

Source: Primary Data on 2019 (UPTD East Kalimantan Provincial Health Laboratory)

All respondents count the number of bacteria has decreased from before irrigated and after irrigated. The decrease in the number of bacteria is in line with previous studies where irrigation can reduce the number of bacteria in diabetic wounds (Yusuf \& Tahir, 2018). Irrigation using betel leaf extract is one method to reduce the number of bacteria (Saputri, 2014). Wound washing is essential in reducing bacterial numbers (Pramesti et al., 2017b)
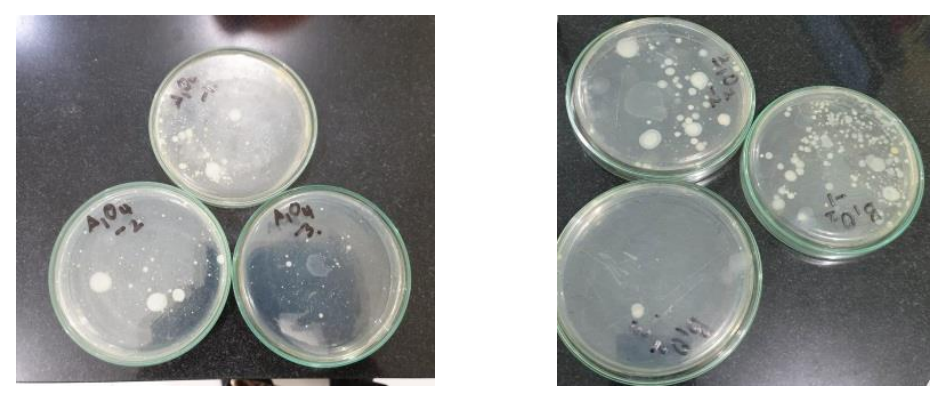

Figure 5.1 bacterial number samples 


\section{Journal Of Nursing Practice}

http://thejnp.org

ISSN: 2614-3488 (print); 2614-3496 (online)

Vol.4 No.1. October 2020. Page.51-60

\section{DISCUSSION}

From the table above shows the most significant decrease in bacterial numbers is in A4 respondents from $147000 \mathrm{CFU}$ to $11125 \mathrm{CFU}$ with the difference in the reduction of $135875 \mathrm{CFU}$. The study is in line with previous studies where wound washing by wound irrigation using betel extract, $20 \%$ can reduce the total bacterial number of diabetic ulcer isolates in white mice alloxan-induced (Purwaningsih, 2016). Red betel extract contains flavanoid, polyphenolate and tannin compounds that function antibacterial (Eka Wisnu Kusuma, 2019)

From the five respondents, Wilcoxon statistical tests carried out, the data in the table below obtained as follows:

The group giving $20 \%$ red betel extract in diabetic foot infection wounds showed no significant difference in the count of bacteria before and after giving $20 \%$ betel extract with a significant value of 0.109 . Small differences in clinical results can be statistically significant if the number of subjects is huge. Conversely, very striking clinical differences can be statistically meaningful if the subjects are too few, this phenomenon formulated. Too many subjects prove everything; too few subjects prove nothing. (Sastroasmoro, 2014) Limited research time resulted in insufficient sample size

From table 5.2 above shows, the most significant decrease in bacterial numbers was in B2 respondents from $19133 \mathrm{CFU}$ to $11 \mathrm{CFU}$ with a difference in the reduction of 19122 CFU. Wound irrigation using $40 \%$ red betel infusion can accelerate wound healing, wound healing that is quickly influenced by the decrease in the number of bacteria in the wound where the number of bacteria is an inhibiting factor in wound healing (Pashar, 2018). Contamination of bacterial colonies on wounds increases the burden of bacteria on wounds prolonging healing and growing cases of chronic wounds (Atiyeh et al., 2009)

The group giving $40 \%$ red betel extract in diabetic foot infection wounds showed no significant difference. Small differences in clinical results can be statistically significant if the number of subjects is huge. Conversely, very striking clinical differences can be statistically meaningful if the subjects are too few; this phenomenon can be formulated. Too many subjects prove everything; too few subjects prove nothing. (Sastroasmoro, 2014) the number of bacteria before and after giving betel extract $40 \%$ with a significant value of 0.109 .

From table 5.2 shows the most significant decrease in bacterial numbers was on $\mathrm{C} 2$ respondents from $79622 \mathrm{CFU}$ to $1000 \mathrm{CFU}$ with a difference of $69622 \mathrm{CFU}$ reduction. Washing wounds using $\mathrm{NaCl}$ can reduce bacterial numbers (Pramesti et al., 2017b) (Pramesti et al., 2017a). Wound washing is an essential step in a series of wound care that can control infection and accelerate wound healing. Controlling bacterial colony contamination is an excellent wound care measure (Atiyeh et al., 2009). The control group with $0.9 \% \mathrm{NaCl}$ irrigation in diabetic foot infections wounds showed no significant difference in the number of bacteria before and after $\mathrm{NaCl}$ irrigation $0.9 \%$ with a significant value of 0.180 . From the table above, the average value of the $20 \%$ group has decreased in bacterial count 10544 CFU. The average amount of the $40 \%$ group has reduced in bacterial count $19104 \mathrm{CFU}$, and the average value of the control group has decreased $6150 \mathrm{CFU}$. The most significant decrease in bacterial count in the three groups was in the group giving $40 \%$ red betel extract irrigation, which was $19104 \mathrm{CFU}$. The $25 \%$ red betel extract can maintain inhibitory levels and minimal kill rate against streptococcus aureus bacteria (Juliantina, M, \& Nirwani, 2009). In conditions of levels of more than 10\%, 20\%, 40\%, 80\%, and $100 \%$ can inhibit staphylococcus aureus, the higher the concentration, the more inhibitory inhibition against bacteria (Candrasari et al., 2011). One of the most bacteria in diabetic foot infections is a staphylococcus aureus (Jneid et al., 2017) 


\section{Journal Of Nursing Practice}

http://thejnp.org

ISSN: 2614-3488 (print); 2614-3496 (online)

Vol.4 No.1. October 2020. Page.51-60

Table 5.6 Frequency distribution calculate the bacterial numbers in all three groups

\begin{tabular}{lrrrrrr}
\hline & $\begin{array}{c}\text { Pre20 } \\
(\mathrm{n}=5)\end{array}$ & $\begin{array}{r}\text { post20 } \\
(\mathrm{n}=5)\end{array}$ & $\begin{array}{c}\text { pre40 } \\
(\mathrm{n}=3)\end{array}$ & $\begin{array}{c}\text { post40 } \\
(\mathrm{n}=3)\end{array}$ & $\begin{array}{c}\text { Precontrol } \\
(\mathrm{n}=2)\end{array}$ & $\begin{array}{r}\text { Postcontrol } \\
(\mathrm{n}=2)\end{array}$ \\
\hline Mean & 38528 & 10544 & 27233 & 19104 & 42961 & 6150 \\
Median & 372 & 60 & 19133 & 11 & 42961 & 6150 \\
Range & 146999 & 41532 & 62432 & 57299 & 73322 & 7700 \\
Minimum & 1 & 1 & 68 & 1 & 6300 & 2300 \\
Maximum & 147000 & 41533 & 62500 & 57300 & 79622 & 10000 \\
\hline
\end{tabular}

Calculate the number of bacteria before and after administration of $20 \%$ red betel irrigation on DFI wounds, which has an average difference of 10544 CFU. Calculate the number of bacteria before and after the administration of $40 \%$ red betel irrigation in DFI sores with an average difference of $19104 \mathrm{CFU}$. Calculate bacterial numbers before and after administration of $0.9 \% \mathrm{NaCl}$ irrigation in DFI sores, with an average difference of 6150 $\mathrm{CFU}$. Calculate the number of bacteria in giving red betel irrigation $20 \%, 40 \%$, and $\mathrm{NaCl}$ $0.9 \%$.

\section{STUDY LIMITATIONS}

This study has several limitations, as follows:

1. The inspection of samples cannot be done at any time because samples can be received during working hours from 8:00 to 11:00 so that the swab wound sampling can only be done in the morning.

2. The number of samples is limited so that it affects the results of statistical tests

3. The results of irrigation using red betel extract reduce the number of bacteria in the wound. But they have not been able to identify which betel content has the most role in reducing the number of these bacteria, so that isolation or separation of red betel content needed in observing research respondents in full daily cannot yet be carried out.

\section{CONCLUSIONS}

There was a decrease in the number of bacteria after irrigation betel leaf extract in all groups. The DFI wound had an average difference in all groups but was not significant. The suggestion for research follows: Taking more samples use of red betel extract as an alternative for infection control in wounds. Further research can be done by isolating the red betel content.

\section{ACKNOWLEDGMENT}

All research funding came from the Faculty of Medicine Mulawarman University grant, and I am expressing my gratitude to the Faculty of Medicine for providing the opportunity to participate in this research. This research has received approval from respondents, and the publication of articles with the principle of confidentiality of respondents. 


\section{Journal Of Nursing Practice}

http://thejnp.org

ISSN: 2614-3488 (print); 2614-3496 (online)

Vol.4 No.1. October 2020. Page.51-60

\section{REFERENCES}

Armstrong, D. G., Boulton, A. J. M., \& Bus, S. A. (2017). Diabetic Foot Ulcers and Their

Recurrence. New England Journal of Medicine, 376(24), 2367-2375.

https://doi.org/10.1056/NEJMra1615439

Atiyeh, B. S., Dibo, S. A., \& Hayek, S. N. (2009). Wound cleansing, topical antiseptics and wound healing. International Wound Journal, 6(6), 420-430. https://doi.org/10.1111/j.1742-481X.2009.00639.x

Badan POM RI. (2010). Acuan sediaan herbal. In Appl. Phys. A (Kelima, Vol. 73). Jakarta: Badan Pengawas Obat dan Makanan Republik Indonesia.

Baranoski, S., \& Ayello, E. (2015). Wound Care Essentials (4th ed.). New York: Lippincott Williams \& Wilkins (LWW). Retrieved from https://www.researchgate.net/publication/306170832_Wound_care_essentials_Prac tice principles_Fourth_edition

Benjamin A. Lipsky, Anthony R. Berendt, Paul B. Cornia, James C. Pile, Edgar J. G. Peters, D. G. A., \& H. Gunner Deery, John M. Embil, Warren S. Joseph, Adolf W. Karchmer, 10 Michael S. Pinzur, and E. S. (2013). Highlights from 2012 infectious diseases society of America clinical practice guidelines for the diagnosis and treatment of diabetic foot infections. Infectious Diseases in Clinical Practice, 21(1), 43-45. https://doi.org/10.1093/cid/cis346

Beta Subakti Nata'atmadja, I. D. (2013). Buletin Penelitian RSUD RS Dr. Soetomo. Badan Penelitian Dan Pengembangan RSUD Dr. Soetomo, pp. 49-98. Retrieved from http://repository.unair.ac.id/45267/1/karil_6.pdf

Candrasari, A., Romas, M. A., \& Astuti, O. R. (2011). Uji daya antimikroba ekstrak etanol daun sirih merah (antimikroba (Piper Crocatum Ruiz \& Pav.) terhadap pertumbuhan Staphylococcus aureus ATCC 6538, Eschericia coli ATCC 11229 dan Candida albicans ATCC 10231 secara in vitro. Biomedika, 5(1), 9-16. https://doi.org/10.23917/biomedika.v4i1.258

Dharma, K. K. (2011). Metodologi Penelitian Keperawatan(Pedoman Melaksanakan dan Menerapkan Hasil Penelitian) (15th ed.). Jakarta: Trans Info Media. Retrieved from https://kink.onesearch.id/Record/IOS3722.SULSE000000000106067/Preview

Dowd, S. E., Wolcott, R. D., Sun, Y., McKeehan, T., Smith, E., \& Rhoads, D. (2008). Polymicrobial nature of chronic diabetic foot ulcer biofilm infections determined using bacterial tag encoded FLX amplicon pyrosequencing (bTEFAP). PLOS ONE, 3(10). https://doi.org/10.1371/journal.pone.0003326

Eka Wisnu Kusuma, D. A. (2019). Karakterisasi Ekstrak Daun Sirih Merah. Jurnal Kesehatan Kusuma Husada, 0017(0), 71-76. Retrived from http://jurnal.ukh.ac.id/index.php/JK/article/view/331/281

Gaol, Y. E. L., Erly, \& Elmatris Sy. (2017). Pola Resistensi Bakteri Aerob pada ada Ulkus Diabetik Terhadap Beberapa Antibiotika di Laboratorium Mikrobiologi RSUP Dr. M. Djamil Padang Tahun 2011-2013. Jurnal.fk.unand.ac.id, 6(1), 164-170. https://doi.org/10.25077/jka.v6i1.664

Gayatri, D. (2008). The Effectiveness Comparison of Betel Solution and Normal Saline to Accelerate of Wound Healing on Infected Diabetic Ulcer. Disertasi. Universitas Indonesia. Jakarta.

I Made Sukma Wijaya. (2018). Perawatan luka dengan pendekatan multidisiplin (I; R. I. Utami, Ed.). Yogyakarta: ANDI.

Jneid, J., Lavigne, J. P., La Scola, B., \& Cassir, N. (2017). The diabetic foot microbiota: A review. Human Microbiome Journal, 5-6(November), 1-6.

https://doi.org/10.1016/j.humic.2017.09.002 


\section{Journal Of Nursing Practice}

http://thejnp.org

ISSN: 2614-3488 (print); 2614-3496 (online)

Vol.4 No.1. October 2020. Page.51-60

Juliantina, F., M, D. A. C., \& Nirwani, B. (2009). Manfaat sirih merah (piper crocatum) sebagai agen antibakterial terhadap bakteri gram positif dan gram negatif. $J$

Kedokteran Dan Kesehatan Indonesia, 1(1). Retrieved from https://www.researchgate.net/publication/277240292_Manfaat_Sirih_Merah_Piper _crocatumsebagai_Agen_Anti_Bakterial_terhadap_Bakteri_Gram_Positif_dan_Ba kteri_Gram_Negatif

Mustofa, I. (2017). Alkaloid immunomodulatory effects of sambiloto ( andrographis paniculate 1. ) On the response of gamma interferon and t. Advances in Natural and Applied Sciences, 9(February 2019), 154-158. Retrieved from https://go.gale.com/ps/anonymous?id=GALE\%7CA505467538\&sid=googleSchola

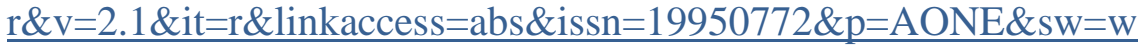

Pashar, I. (2018). Efektifitas pencucian luka menggunakan larutan $\mathrm{NaCl} 0,9 \%$ dan kombinasi larutan $\mathrm{NaCl}$ 0,9\% dengan infusa daun sirih merah $40 \%$ terhadap proses penyembuhan ulkus diabetik. Repository.unimus.ac.id, (April), 1-19. Retrieved from http://repository.unimus.ac.id/1921/

Pereira, S. G., Moura, J., Carvalho, E., \& Empadinhas, N. (2017). Microbiota of chronic diabetic wounds: Ecology, impact, and potential for innovative treatment strategies. Frontiers in Microbiology, 8(SEP), 1-12. https://doi.org/10.3389/fmicb.2017.01791

Pramesti, A., Andiyanti, L., \& Effendi, A. (2017a). Evaluation Of Using Wound Cleansers To The Wound Healing : Literature Review. Jurnal Keperawatan Muhammadiyah, 2(2), 14-20.

Pramesti, A., Andiyanti, L., \& Effendi, A. (2017b). Peranan Pencucian Luka Terhadap Penurunan Kolonisasi Bakteri Pada Luka Kaki Diabetes. Jurnal Keperawatan Muhammadiyah, 2(2), 110-115. http://dx.doi.org/10.30651/jkm.v3i2.1829

Purwaningsih, I. (2016). Efektifitas cleansing infusa daun sirih merah (piper crocatum) dalam menurunkan angka bakteri total isolat ulkus diabetikum pada tikus putih yang diinduksi aloksan. (May), 31-48. Retrieved from http://poltekkeskhjogja.ac.id/fasilitas/perpustakaan/repositori/send/11-jurnal-dosen2016/76-efektifitas-cleansing-infusa-daun-sirih-merah-piper-crocatum-terhadappenyembuhan-ulkus-diabetikum-pada-tikus-putih-yang-diinduksi-aloksan

Saputri, W. E. K. A. (2014). Pengaruh Metode Pemberian Ekstrak Daun Sirih Merah (Piper crocatum) Konsentrasi 6,25\% Terhadap Jumlah Koloni Bakteri Aggregatibacter actinomycetemcomitans (Kajian In Vitro). Retrieved from http://etd.repository.ugm.ac.id/penelitian/detail/76639

Sastroasmoro, S. (2014). Dasar-dasar metodologi penelitian klinis (5th ed.). Jakarta: Sagung Seto.

Smith, K., Collier, A., Townsend, E. M., O’Donnell, L. E., Bal, A. M., Butcher, J., ... Williams, C. (2016). One step closer to understanding the role of bacteria in diabetic foot ulcers: Characterising the microbiome of ulcers. BMC Microbiology, 16(1), 1-13. https://doi.org/10.1186/s12866-016-0665-Z

Sutopo, T., Bestari, R. S., \& Sintowati, R. (2017). Uji ekstrak etanol 70\% daun sirih (piper betle 1.) terhadap bleeding time pada mencit jantan galur swiss webster. Biomedika, 8(2), 54-61. Retrieved from http://eprints.ums.ac.id/40603/

Sutrisno, \& Hidayat, D. P. (2018). Efektifitas penggunaan daun jambu biji (psidium guajava) dan daun sirih merah (piper crocatum) terhadap pengontrolan odour (bau) pada pasien luka diabetes mellitus di Fatchul Wound Care (pp. 11-18). pp. 11-18. https://doi.org/10.35720/tscners.v3i1.57 


\section{Journal Of Nursing Practice}

http://thejnp.org

ISSN: 2614-3488 (print); 2614-3496 (online)

Vol.4 No.1. October 2020. Page.51-60

Uçkay, I., Aragón-Sánchez, J., Lew, D., \& Lipsky, B. A. (2015). Diabetic foot infections: What have we learned in the last 30 years? International Journal of Infectious Diseases, 40, 81-91. https://doi.org/10.1016/j.ijid.2015.09.023

Wolcott, R. D., Hanson, J. D., Rees, E. J., Koenig, L. D., Phillips, C. D., Wolcott, R. A., ... White, J. S. (2016). Analysis of the chronic wound microbiota of 2,963 patients by 16S rDNA pyrosequencing. Wound Repair and Regeneration, 24(1), 163-174. https://doi.org/10.1111/wrr.12370

Yusuf, S., \& Tahir, T. (2018). Study literatur penggunaan sabun antiseptik untuk pencucian luka terhadap penurunan kolonisasi bakteri pada pasien dengan luka diabetes.

Jurnal Luka Indonesia, 4(September), 108-122. Retrieved from https://www.researchgate.net/profile/Takdir_Tahir/publication/326080305_LITER ATUR_REVIEW_STUDY_LITERATUR_PENGGUNAAN_SABUN_ANTISEPT IK_UNTUK_PENCUCIAN_LUKA_TERHADAP_PENURUNAN_KOLONISASI BAKTERI_PADA_PASIEN_DENGAN_LUKA_DIABETES_How_to_cite_Noth ing_Nothing_Conflict_of_interes/links/5b36e5b44585150d23e50eb4/LITERATUR -REVIEW-STUDY-LITERATUR-PENGGUNAAN-SABUN-ANTISEPTIKUNTUK-PENCUCIAN-LUKA-TERHADAP-PENURUNAN-KOLONISASIBAKTERI-PADA-PASIEN-DENGAN-LUKA-DIABETES-How-to-cite-NothingNothing-Conflict-of-interes.pdf 